\title{
Network Data Mining Application in Earnings Management of Private Holding Enterprise: An Empirical Analysis Based on Multiple Regression Model
}

\author{
Hongtao Liu* \\ Shaoyang University, Shaoyang, 422000, China \\ Corresponding author: Hongtao Liu,rrsh248@163.com
}

\begin{abstract}
Efficient processing platform can effectively analyze massive data, strong support for data mining algorithms and data visualization. In this paper, the authors use the new path of integration earnings management way and earnings management direction to study the relationship between China's listed companies' ownership structure and earnings management. The results found that: private holding company's earnings quality the pressure is far greater than the state-owned holding company; negative earnings management private holding company level was significantly lower than the state-owned holding company; $U$-shaped relationship between ownership concentration and earnings management, moderate concentration of ownership in favor of reducing the level of earnings management. Accordingly, aspects of equity nature, are intended to promote the development direction of mixed ownership in line with our national interests; the controlling stake in moderate levels of concentration of ownership structure another sign of deepening reform success.
\end{abstract}

Keywords: Data mining, Big data platform, Earnings management, Private holding enterprise

\section{Introduction}

The advent of the era of big data makes the scale and complexity of data explosive growth, prompting the use of data mining technology in different applications of data mining techniques to analyze the data [1-2]. In the process of the formation and development of Chinese stock market, the structure of state-owned holding listed companies is the main structure of the listed companies. And this is a unique feature and deviated from the mainstream paradigm, by the theoretical and practical circles widely criticized, and is known as the China stock market's original sin, so far, allocation of rights of the state owned holding company between large shareholders and small shareholders still exists many unreasonable [3].The dominance of state-owned shares and fause often gathered together to become China's accounting information quality of listed companies to improve the crux of the problem. Fortunately, is in the great period of economic transformation in the private holding company into a fresh $\mathrm{A}$ new force suddenly rises [4-6]. China force of economic development, its strength should not be overlooked, is following, the ownership structure of China has been very special is experiencing a profound change [7]. Therefore, in the past that separate state-owned holding as the research object, the executives shareholding ratio as the starting point to study on earnings management of the company has the urgent need to open up the private holding be inopportune or inappropriate, as the research object in reality, with the proportion of the first shareholder as the starting point of the new perspective to explore the problem of earnings management of the company, improve the quality of accounting information of Listed Companies in China, both in the micro operation of the company, or the macro decision has very practical significance. 
Earnings management is an important field and hot topic in the middle and late 1980s, which belongs to the category of empirical accounting research. As a kind of alienation of accounting behavior, it is an important source of the problem caused by the low quality of accounting information so people conduct research on earnings management, aims at a deeper understanding of the value of accounting earnings and accounting behaviors and mechanism, to further examine the economic consequences of accounting practices and mining the information of earnings allowance thus, help to improve the regulatory policies and accounting standards, optimize corporate governance and improve the market allocation of resources [8-11]. In the way of earnings management, the existing research tends to earnings management from the perspective of earnings management, accruals earnings management is to adjust the book profit in the premise of not changing the inner economic activities of the company, although it is more likely to be aware of auditors and regulators, but have little difficulty handling, the for the characteristics of low cost; but less from the perspective of real earnings management perspective, characteristics of real earnings management is the company through constructing transaction to adjust the profit, though it is not easy to be aware of auditors and regulators, however, difficult operation, the cost is high [13-15]. The main contribution of this paper is: (1) compared with the previous literature, we opened a new perspective for research on earnings management from the private holding company, broaden the research path for the effective governance of Listed Companies in China; (2) the clear direction of earnings management and earnings management in the integration of the channel, making for the effective supervision of the company's accounting standards and provide a new method; (3) take more from the previous earnings and positive earnings perspective to carry out empirical accounting research, and less from the real earnings and negative earnings perspective to study how to improve the lack of characteristics of accounting information quality, fill the blank of local study on earnings management of domestic.

\section{Data Mining and Network Data}

Big data is often used to describe and refer to the mass information generated in the era of information explosion. Study on the significance of data lies in the discovery and understanding between the information content and information and contact information. Data mining comes from the practice in the practical application demand, driven by application specific data as in algorithm, tool and platform as a support, will find the information and knowledge into practice, so as to provide a quantitative reasonable and feasible, can be of immense value to the information. In addition, mining the useful information contained in large data, the need to design and develop the corresponding data mining and machine learning algorithms. The design and development of the algorithm should be driven by the specific application data, and it should be applied and verified in practical problems. Efficient processing platform to effectively analyze massive amounts of data and integration of multi-source data, and the strong support of data mining algorithms and data visualization of the implementation, and to regulate the process of data analysis [16]. In a word, the application of algorithm and data platform and the idea of combining the above data understanding and understanding of a comprehensive and concise, reflects the essence and the core of large data. Build large data mining on this architecture, can effectively deal with the complex characteristics of large data, mining the value of large data. 


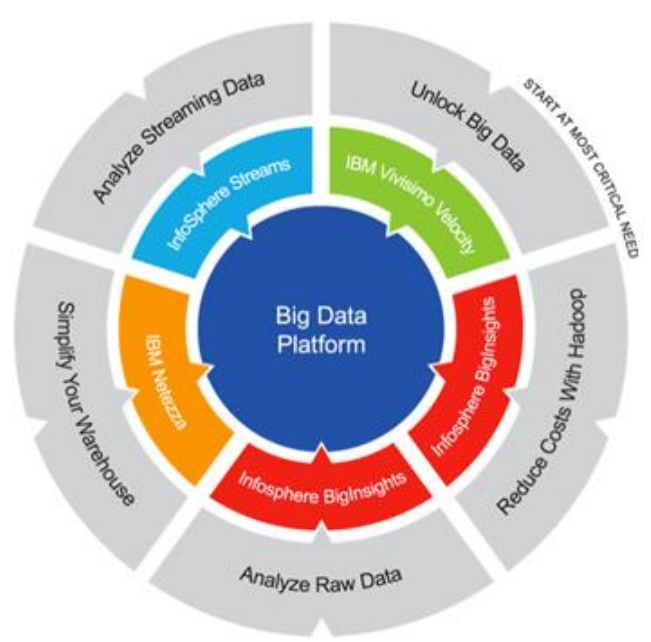

Figure 1. Big Data Platform

In the era of big data, the generation and collection of data is the foundation, data mining is the key. Data mining is the most critical and most valuable work in big data. Usually, data mining or knowledge discovery to find the hidden, unknown but useful information and an engineering model of the potential and systematic process from large amounts of data. Data mining can be summarized in the following 4 characteristics.

- application: Data mining is the perfect combination of theory algorithm and application practice. Data mining from the actual production and life application needs, the data mining from the specific application, and through the knowledge of data mining to be applied to practice, to assist the actual decision-making. Therefore, data mining comes from the application of practice, but also serve the application practice.

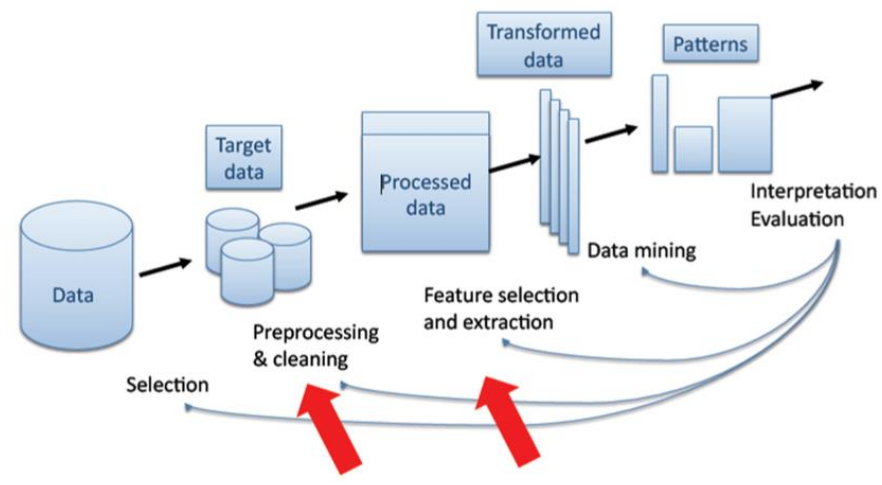

Figure 2. Data Mining

- engineering: Data mining is a process of engineering which is composed of several steps. The application of data mining is decided by the characteristics of data mining is not only the analysis and application of the algorithm, but included a data preparation and management, data processing and conversion, the integrity of the process of development and application of mining algorithm, and the results demonstrate and validate the knowledge accumulation and use. And in practical applications, the typical data mining process is a process of interaction and circulation. 
- collection: Data mining is a collection of various functions. Commonly used data mining functions include data exploration and analysis, association rule mining, time series pattern mining, classification and prediction, clustering analysis, anomaly detection, data visualization and link analysis. A specific application case often involves multiple different functions. Different functions usually have different theoretical and technical basis, and each function has a different algorithm support.

- intersection: Data mining is a cross subject, which uses the research results and academic ideas from statistical analysis, pattern recognition, machine learning, artificial intelligence, information retrieval, database and so on. At the same time, some other fields such as random algorithm, information theory, visualization, distributed computing and optimization play an important role in the development of data mining.

Efficient processing platform to effectively analyze massive amounts of data and integration of multi-source data, and the strong support of data mining algorithms and data visualization of the implementation, and to regulate the process of data analysis. In a word, the application of algorithm and data platform and the idea of combining the above data understanding and understanding of a comprehensive and concise, reflects the essence and the core of large data. Build large data mining on this architecture, can effectively deal with the complex characteristics of large data, mining the value of large data.

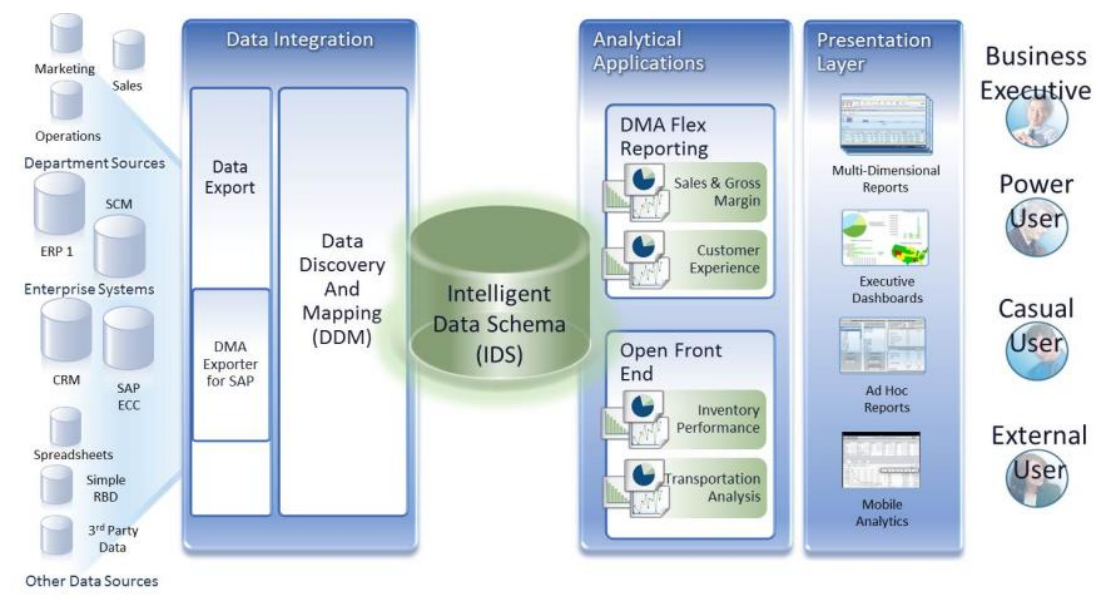

Figure 3. Big Data Mining Platform

\section{Literature Review and Research Hypothesis}

Relative to the private holding companies, state-owned holding company requirements on earnings quality of private holding company not strong, this is because the state-owned holding companies are the so-called "owners" phenomenon, and the political connections of most executives, they often face lower financial distress and bankruptcy risk; and this is exactly the opposite. Non state owned holding companies more clarity of property rights, and executives have little or no political capital, will naturally face financial distress and bankruptcy risk more. Based on the difference of the demand pressure of earnings quality, the paper proposes the following hypothesis:

Hypothesis 1: the earnings quality of the private holding companies is greater than the pressure of the state-owned holding companies.

Kato (2006) found that private holding company managers have a greater incentive to forward earnings management to improve the performance of the company's reports in 
order to gain confidence in the market for them. Wang (2014) found in the study of whether the listed companies to get more government subsidies and earnings management, the state-owned enterprises to a loss of negative earnings management, the company can get more government subsidies, thereby triggering a greater degree of resource distortions, thus confirming the negative control of state-owned enterprises more favorable. This paper puts forward the following hypothesis:

Hypothesis 2: the negative earnings management level of the private holding company is lower than that of the state holding company.

In highly decentralized equity, dispersed shareholders own gains and losses will be based on the initiation of the "free rider" idea, no active supervision of the motivation of management; however, with the option to enhance the degree of concentration, big shareholders, the situation is another matter, at this time, the old "vote by foot" situation become less, "short-term speculation" phenomenon is difficult to visible, which may manifest as effect of convergence of interests between shareholders and managers. Monks and Minow (1995) also believe that corporate shareholders have the motivation, resources and has the ability to affect the company's supervision, restriction and management, the real earnings reports of listed companies will be more inclined to the reaction of business (general corporate shareholders holding shares is relatively large; however, high) in a certain proportion of equity after the big shareholders must have control of the company beyond their equity ratio, such as large shareholders control the internal sources of outside investors are unable to know, resulting in serious information asymmetry between large shareholders and outside investors, this asymmetry will induce large shareholders to manipulate earnings report through the strong motivation to conceal and mislead investors may, through internal transactions to encroach on the interests of small shareholders, which reflected the interests of the occupation effect. Based on the profound changes in the ownership structure of our country, this paper puts forward the following hypothesis:

Hypothesis 3: the ownership concentration is $U$ relationship between the degree of earnings management and, when ownership concentration is small, the convergence of interest effect is activated, the ownership concentration is negatively correlated with the degree of earnings management; and when the ownership concentration is high, the interests of the occupation effect is activated, ownership concentration and earnings management is positively correlated.

\section{Variables and Measurement Model}

\subsection{Econometric Model}

(1).Accrued earnings management estimate

The accrual earnings management, we use Jones model to calculate, taking into account the Kothari (2005) years found that adding intercept and company asset returns in the model (ROA). First of all, using the data of different industries in different years of the model (1) by OLS regression, regression, and obtained parameters $a_{0}, a_{0}, a_{1}, a_{2}$, $a_{3}, a_{4}$ then, into the model (2) can not be calculated in discretionary accruals. Finally, total accruals and discretionary accruals to do bad, you can get the discretionary accruals value.

$$
\begin{gathered}
\frac{{T A_{i t}}_{i t}}{\text { Assets }_{i, t-1}}=a_{0}+a_{1} \frac{1}{\text { Assets }_{i, t-1}}+a_{2} \frac{\text { DREV }_{i t}-\text { DREC }_{i t}}{\text { Assets }_{i, t-1}}+a_{3} \frac{P P E_{i t}}{\text { Assets }_{i, t-1}}+a_{4} \text { ROA }_{i, t-1}+\varepsilon_{i t} \\
N A_{i t}=\hat{a}_{0}+\hat{a}_{1} \frac{1}{\text { Assets }_{i, t-1}}+\hat{a}_{2} \frac{\operatorname{DREV}_{i t}-\operatorname{DREC}_{i t}}{\text { Assets }_{i, t-1}}+\hat{a}_{3} \frac{P P E_{i t}}{\text { Assets }_{i, t-1}}+\hat{a}_{4} \text { ROA }_{i, t-1}
\end{gathered}
$$

Model (1) the $\mathrm{TA}_{\mathrm{it}}$ represents the total accruals, it is EBXI $\mathrm{it}_{\mathrm{it}}$ minus the results of $\mathrm{CFO}_{\mathrm{it}}$, I and T company for the fiscal year, net profit of EBXI on behalf of the company I in the 
year of t CFO, said the net cash flow of I company in the T annual business activities. Model (2) in the $\mathrm{NA}_{\mathrm{it}}$ on behalf of the non discretionary accrual, its content is interpreted as a variable $\mathrm{TA}_{\mathrm{it}} / \mathrm{Assetsi}_{\mathrm{t}-1}$ in the sample interval of the fitting value (values fitted). Model (1) and model (2) in Assetsit-1 on behalf of I in the total assets of the T-1 year end, each variable divided by the purpose of it is to eliminate the influence of the size of the company; $\mathrm{REV}_{\text {it }}$ said the $\mathrm{T}$ and the $\mathrm{T}-1$ difference between the annual main business income of the year; $\mathrm{REC}_{\mathrm{it}}$ said $\mathrm{t}$ year and $\mathrm{T}-1$ the annual balance of accounts receivable; $\mathrm{PPE}_{\mathrm{it}}$ said the $\mathrm{t}$ at the end of the annual fixed assets; on this basis, $\mathrm{TA}_{\mathrm{it}} / \mathrm{Assetsi}_{\mathrm{t}-1}$ and $\mathrm{NA}_{\mathrm{it}}$ as the difference of discretionary accruals $\left(\mathrm{DA}_{\mathrm{it}}\right)$ estimates.

(2). Real earnings management estimate

According to Dechow et al. (1998) development, Roychowdhury (2006) is used to model the empirical operating cash flow with sales (Sales) in the presence of linear relationships as shown in (3):

$$
\frac{\text { CFO }_{i t}}{\text { Assets }_{i, t-1}}=b_{0}+b_{1} \frac{1}{\text { Assets }_{i, t-1}}+b_{2} \frac{\text { Sales }_{i t}}{\text { Assets }_{i, t-1}}+b_{3} \frac{\text { DSales }_{i t}}{\text { Assets }_{i, t-1}}+\varepsilon_{i t}
$$

There is a linear relationship between the cost of product sales ( $C O G S$ ) and the same year sales (4):

$$
\frac{\operatorname{COGS}_{i t}}{\operatorname{Assets}_{i, t-1}}=b_{0}+b_{1} \frac{1}{\operatorname{Assets}_{i, t-1}}+b_{2} \frac{\text { Sales }_{i t}}{\text { Assets }_{i, t-1}}+\varepsilon_{i t}
$$

There is a linear relationship between the amount of inventory changes $(\triangle I N V)$ and changes in the same year and the previous year's sales, as (5):

$$
\frac{\text { DINV }_{i t}}{\text { Assets }_{i, t-1}}=b_{0}+b_{1} \frac{1}{\text { Assets }_{i, t-1}}+b_{2} \frac{\text { DSales }_{i t}}{\text { Assets }_{i, t-1}}+b_{3} \frac{\text { DSales }_{i t-1}}{\text { Assets }_{i, t-1}}+\varepsilon_{i t}
$$

According to the formula (4) and (5), we can estimate the normal production cost, and the results are as following: (6):

$$
\frac{\text { PROD }_{i t}}{\text { Assets }_{i, t-1}}=b_{0}+b_{1} \frac{1}{\text { Assets }_{i, t-1}}+b_{2} \frac{\text { Sales }_{i t}}{\text { Assets }_{i, t-1}}+b_{3} \frac{\text { DSales }_{i t}}{\text { Assets }_{i, t-1}}+b_{4} \frac{\text { DSales }_{i t-1}}{\text { Assets }_{i, t-1}}+\varepsilon_{i t}
$$

There is a linear relationship between the normal discretionary expenses () and the previous year's sales, as shown in (7):

$$
\frac{\operatorname{DISEXP}_{i t}}{\text { Assets }_{i, t-1}}=b_{0}+b_{1} \frac{1}{\text { Assets }_{i, t-1}}+b_{2} \frac{\text { Sales }_{i t-1}}{\text { Assets }_{i, t-1}}+\varepsilon_{i t}
$$

On the basis of the work above, the use of 2009-2015 data, the type (3), (6) and (7) were performed OLS regression, obtain their parameter estimates, and then get the cash flow from operating activities (CFOit), $\left(\mathrm{PROD}_{\mathrm{it}}\right)$ the product cost and handling cost $\left(D_{\text {ISEXP }}\right.$ it) fitting value in order to estimate the normal values; then, the year the actual value difference occurred and the estimated normal value, can obtain the cash flow abnormal operating activities (R_CFO ${ }_{i t}$ ), abnormal product cost (R_PROD ${ }_{i t}$ ) and abnormal handling fee (R_DISEXP $\mathrm{it}_{\mathrm{it}}$ ); finally, considering the Choen (2008) may be offset between the different real earnings management activities proposed by the formula (8) for the overall measurement indicators of earnings management $(\mathrm{RM})$ :

$$
R M=R \_P R O D_{i t}-R \_C F O_{i t}-R \_D I S E X P_{i t}
$$

This paper believes that not only the nature of the equity will affect the company's earnings management behavior, but also the degree of concentration of ownership will affect the company's earnings management. To this end, this paper sets the following regression model (9):

$$
\begin{aligned}
& E M=c_{0}+c_{1} \text { Private }_{i t}+c_{2} \text { Topl }_{i t}+c_{3}(\text { Top1 })_{i t}^{2}+c_{4} B M_{i t}+c_{5} \text { SIZE }_{i t}+c_{6} S T_{i t} \\
& +c_{7-17} \sum \text { Industry }+c_{18-19} \sum \text { Year }+\varepsilon
\end{aligned}
$$




\subsection{Sample Selection and Data}

This paper choose China Shanghai and Shenzhen 20082014 years of non-financial listed companies as the primary data, the following selection of samples: (1) considering the particularity of the financial services industry, financial companies are excluded from the sample; (2) because the issuing B shares or H shares not face the same regulatory environment, so also from the sample culling; (3) due to the need of the study according to the nature of the controller to classify the Sample Firms, the nature of the ultimate controller of the listed company is to be removed from the sample; (4) the lack of data and the existence of extremal, the company also excluded from the analysis. At the end of the year we have an annual observation of 6045 . The data of this paper comes from the CSMAR database.

Table 1. Variables and Define

\begin{tabular}{|c|c|c|c|}
\hline variable & Name & Variable description & Variable definition \\
\hline \multirow[t]{5}{*}{$\begin{array}{l}\text { explained } \\
\text { variable }\end{array}$} & Abs_DA & $\begin{array}{l}\text { Accrual earnings } \\
\text { management }\end{array}$ & $\begin{array}{l}\text { Absolute value of discretionary } \\
\text { accrual }\end{array}$ \\
\hline & R_CFO & $\begin{array}{l}\text { Abnormal operating cash } \\
\text { flow }\end{array}$ & $\begin{array}{l}\text { Absolute value of abnormal } \\
\text { operating cash flow }\end{array}$ \\
\hline & R_PROD & $\begin{array}{l}\text { Abnormal production } \\
\text { cost }\end{array}$ & Absolute value of abnormal cost \\
\hline & R_DISEXP & $\begin{array}{l}\text { Abnormal handling } \\
\text { charge }\end{array}$ & $\begin{array}{c}\text { Absolute value of abnormal } \\
\text { handling charges }\end{array}$ \\
\hline & RM & $\begin{array}{l}\text { Real earnings } \\
\text { management }\end{array}$ & Absolute value of real earnings \\
\hline \multirow[t]{3}{*}{$\begin{array}{l}\text { Explanatory } \\
\text { variable }\end{array}$} & Private & Equity nature & $\begin{array}{c}\text { Dummy variable, when the stock is } \\
\text { private, take } 1 \text {, or take } 0\end{array}$ \\
\hline & Top1 & Ownership concentration & $\begin{array}{l}\text { The share ratio of the largest } \\
\text { shareholder of the company }\end{array}$ \\
\hline & Top $1^{2}$ & Square term & $\begin{array}{l}\text { The square of Ownership } \\
\text { concentration }\end{array}$ \\
\hline \multirow[t]{5}{*}{$\begin{array}{l}\text { control } \\
\text { variable }\end{array}$} & $\mathrm{BM}$ & book-to-market & $\begin{array}{l}\text { Ratio of total assets to total assets } \\
\text { in the market }\end{array}$ \\
\hline & Size & company size & Natural logarithm of total assets \\
\hline & ST & Trading status & $\begin{array}{c}\text { Dummy variable, the company is in } \\
\text { ST state always take } 1 \text {, otherwise } \\
\text { take } 0\end{array}$ \\
\hline & Industry & Industry variables & $\begin{array}{l}\text { Dummy variable, belonging to the } \\
\text { industry take } 1 \text {, otherwise take } 0\end{array}$ \\
\hline & Year & Annual variable & $\begin{array}{c}\text { Dummy variable, belonging to the } \\
\text { year take } 1 \text {, otherwise take } 0\end{array}$ \\
\hline
\end{tabular}




\section{Empirical Analysis}

\subsection{Descriptive Statistical Analysis}

Table 2 reports descriptive statistics of the main variables in the full sample. The full sample of accrued earnings (Abs_DA) the average value is 0.0732, and the minimum and maximum values were 0 and 9.6778; the degree of real earnings management (RM) the average value is 0.2085 , the minimum and maximum values were 0 and 44.6854 .

Table 2. All Sample Descriptive Statistics

\begin{tabular}{|c|c|c|c|c|c|}
\hline variable & Observation & $\begin{array}{c}\text { average } \\
\text { value }\end{array}$ & $\begin{array}{c}\text { standard } \\
\text { deviation }\end{array}$ & $\begin{array}{c}\text { minimum } \\
\text { value }\end{array}$ & $\begin{array}{c}\text { Maximum } \\
\text { value }\end{array}$ \\
\hline Abs-DA & 6045 & 0.0732 & 0.1662 & 0.0000 & 9.6778 \\
\hline R_CFO & 6045 & 0.0757 & 0.1185 & 0.0000 & 3.7591 \\
\hline R_PROD & 6045 & 0.1217 & 0.7127 & 0.0000 & 46.6411 \\
\hline R_DISEXP & 6045 & 0.0574 & 0.0942 & 0.0000 & 3.3075 \\
\hline RM & 6045 & 0.2085 & 0.7415 & 0.0000 & 44.6854 \\
\hline Private & 6045 & 0.3259 & 0.4687 & 0.0000 & 1.0000 \\
\hline Top1 & 6045 & 36.1807 & 15.4987 & 2.1969 & 86.3473 \\
\hline Top12 & 6045 & 1549.2130 & 1263.2660 & 4.8264 & 7455.856 \\
\hline Bm & 6045 & 0.6612 & 0.2874 & 0.0347 & 2.5653 \\
\hline Size & 6045 & 21.5352 & 1.5306 & 12.8008 & 28.6889 \\
\hline ST & 6045 & 0.0265 & 0.1605 & 0.0000 & 1.0000 \\
\hline
\end{tabular}

Table 3 reports descriptive statistics of the main variables in the sub sample. From the statistical average value of the test results, the state-owned listed companies of real earnings management and earnings management degree was significantly lower than that of private listed companies, which shows that: first, listed companies generally have accrued and real earnings management of listed companies; secondly, the different nature of the right stock accrual and real earnings the management level there is a big difference, and the extent of earnings management of listed private holding companies more efficient, and consistent hypothesis 1 .

Table 3. Sub Sample Descriptive Statistics

\begin{tabular}{|c|c|c|c|c|c|c|c|c|}
\hline \multirow{2}{*}{ varible } & \multicolumn{3}{|c|}{ State-run } & \multicolumn{3}{c|}{ privately operated } & \multicolumn{2}{c|}{ difference } \\
\cline { 2 - 9 } & $\begin{array}{c}\text { Obs } \\
\text { e }\end{array}$ & Aver & S.D. & Obse & Aver & S.D. & $\begin{array}{c}\text { Mean } \\
\text { difference }\end{array}$ & t test \\
\hline Abs-DA & 4075 & 0.0632 & 0.0831 & 1970 & 0.0973 & 0.2629 & -0.0341 & $-6.1190^{* * *}$ \\
\hline R_CFO & 4075 & 0.0704 & 0.0796 & 1970 & 0.0859 & 0.1612 & -0.0155 & $-4.1986 * * *$ \\
\hline R_PROD & 4075 & 0.0972 & 0.1287 & 1970 & 0.1698 & 1.2313 & -0.0726 & $-3.3984 * * *$ \\
\hline $\begin{array}{c}\text { R_DISEX } \\
\text { P }\end{array}$ & 4075 & 0.0522 & 0.0680 & 1970 & 0.0665 & 0.1318 & -0.0143 & $-3.8684 * * *$ \\
\hline RM & 4075 & 0.1826 & 0.2080 & 1970 & 0.2610 & 1.2613 & -0.0784 & $-3.7177 * * *$ \\
\hline Private & 4075 & 0.000 & 0.000 & 1970 & 1.0000 & 0.0000 & -1.0000 & \\
\hline Top1 & 4075 & 39.0074 & 15.4388 & 1970 & 30.3336 & 13.9076 & 8.6738 & $21.1330 * * *$ \\
\hline Top1 ${ }^{2}$ & 4075 & 1759.87 & 1297.57 & 1970 & 1113.44 & 1064.45 & 646.4280 & $19.2068 * * *$ \\
\hline Bm & 4075 & 0.7016 & 0.2867 & 1970 & 0.5776 & 0.2703 & 0.1240 & $16.0477 * * *$ \\
\hline Size & 4075 & 21.8520 & 1.4843 & 1970 & 20.8800 & 1.4124 & 0.9720 & $24.2418 * * *$ \\
\hline ST & 4075 & 0.0258 & 0.1585 & 1970 & 0.0279 & 0.1648 & -0.0021 & -0.4885 \\
\hline
\end{tabular}

Note: $* * *, * * *$ are significant at $0.1,0.5$ and 0.01 , respectively. 
Table 4 provides an analysis of the correlation between variables. We found that AbsDA was significantly positively correlated with RCFO, RPROD, RDISEXP, and RM at the 0.01 level. A significant positive correlation between AbsDA and Private, showed that accruals is highly sensitive to the nature of equity; a significant positive correlation between AbsDA and ST, shows that the company is in the ST state, the more will induce earnings management; AbsDA and BM, SIZE showed significant negative correlation, scale (SIZE) is the company listed company market to book ratio (BM) higher, more effective accrual earnings management. Real earnings management (RM) and accrual earnings management is just the opposite, RM and TOP1 and TOP12 are significantly positive correlation, which shows that the real surplus has a high degree of sensitivity of the equity concentration.

Table 4. The Main Variable Correlation Test

\begin{tabular}{|c|c|c|c|c|c|c|c|c|c|c|c|}
\hline & Abs-DA & R_CFO & $\begin{array}{c}\text { R_PRO } \\
\text { D }\end{array}$ & $\begin{array}{c}\text { R_DISEX } \\
\text { P }\end{array}$ & RM & Private & Top1 & Top12 & $\mathrm{Bm}$ & Size & $\begin{array}{l}\mathrm{S} \\
\mathrm{T}\end{array}$ \\
\hline Abs-DA & 1 & & & & & & & & & & \\
\hline R_CFO & $0.4622^{* * *}$ & 1 & & & & & & & & & \\
\hline R_PROD & $\underset{*}{0.3311^{* 8}}$ & $\begin{array}{c}0.3703^{* *} \\
*\end{array}$ & 1 & & & & & & & & \\
\hline $\mathrm{R}_{-}$_DISEX & $\underset{*}{0.2172^{* *}}$ & $\underset{*}{0.3853^{* *}}$ & $0.5005^{* *}$ & 1 & & & & & & & \\
\hline RM & $\begin{array}{c}0.3522^{* *} \\
*\end{array}$ & $\begin{array}{c}0.4600^{* *} \\
*\end{array}$ & $0.9782^{* *}$ & $0.5764^{* * 8 *}$ & 1 & & & & & & \\
\hline Private & $0.0785^{* *}$ & $\begin{array}{c}0.0539^{* *} \\
*\end{array}$ & 0.0437 & $0.0497^{* * *}$ & 0.0478 & 1 & & & & & \\
\hline Top1 & -0.0138 & $\begin{array}{c}0.0718^{* *} \\
*\end{array}$ & $\underset{*}{0.0526^{* *}}$ & 0.0437 & $\underset{*}{0.0593^{* *}}$ & $0.2623^{* *}$ & 1 & & & & \\
\hline Top12 & -0.0041 & $\mathrm{O}_{*}^{0.0835^{* * *}}$ & $\begin{array}{c}0.0606^{* *} \\
*\end{array}$ & $0.0545^{* * * *}$ & $0.0673^{* * *}$ & $\underset{*}{0.2399^{* *}}$ & $0.9732^{* * 8}$ & 1 & & & \\
\hline $\mathrm{Bm}$ & $\underset{*}{0.0625^{* *}}$ & -0.0207 & 0.013 & $-0.0504^{* * *}$ & 0.0024 & $0.2022^{* *}$ & $\begin{array}{c}0.2045^{* *} \\
*\end{array}$ & $\begin{array}{c}0.2094^{* *} \\
*\end{array}$ & 1 & & \\
\hline Size & $\underset{*}{0.0835^{* *}}$ & 0.0142 & 0.0271 & $0.0705^{* * *}$ & 0.0405 & $\underset{*}{0.2977 * *}$ & $\underset{*}{0.3100^{* *}}$ & $\underset{*}{0.3185^{* *}}$ & $0.5011^{* *}$ & 1 & \\
\hline ST & $0.0428^{* *}$ & 0.0202 & -0.0066 & -0.0064 & -0.012 & 0.0063 & -0.0248 & -0.0247 & -0.0394 & $\underset{*}{0.0924^{* *}}$ & 1 \\
\hline
\end{tabular}

\subsection{Results and Analysis of Multiple Regression}

Table 5 reports the results of multiple regression analysis of the accrual earnings management model. From the full sample of listed companies should be regression results of earnings management can be seen: the nature of equity (Private) at the 0.01 level was positively correlated with earnings, that is closer to the private nature of equity, the accrual earnings management motivation is more intense, the results show that the 1 hypothesis is true. If we measure the earnings according to the values of the symbols will be divided into positive earnings accrued earnings $(D A>0)$ and negative accruals $(D A<0)$, found that after grouping return: the nature of equity (Private) in positive accruals under DA+ model whose coefficient is significantly positive, in DA- mode the coefficient is significantly negative, that is closer to the nature of private equity, the more likely positive control of accrued earnings, while equity is closer to the state, the more likely that negative manipulation of earnings management, which supports the hypothesis 2 . 
Table 5. Equity Nature and Accrued Earnings Management

\begin{tabular}{|c|c|c|c|}
\hline $\mathrm{DA}$ & Abs-DA & $\mathrm{DA}+$ & DA- \\
\hline Private & $0.0202 * * * \quad[0.0000]$ & $0.0347 * * * \quad[0.0000]$ & $-0.0062^{*}$ \\
\hline Top1 & $-0.0013 * * \quad[0.0260]$ & $-0.0019^{*}$ & $0.0007 *$ \\
\hline Top12 & $0.0000 * * * \quad[0.0060]$ & $0.0000 * *$ & $0.0000 *$ \\
\hline $\mathrm{BM}$ & $-0.027 * * * \quad[0.0060]$ & {$[0.2060]$} & $0.0295^{* * *} \quad[0.0000]$ \\
\hline SIZE & $-0.005^{* * *} \quad[0.0040]$ & $-0.0073 * * \quad[0.0420]$ & $0.0049 * * * \quad[0.0000]$ \\
\hline ST & $0.0408 * * * \quad[0.0020]$ & [0.7780] & $-0.060 * * * \quad[0.0000]$ \\
\hline Cons & $0.2169^{* * *} \quad[0.0000]$ & $0.2650 * * * \quad[0.0010]$ & $-0.214 * * * \quad[0.0000]$ \\
\hline Industry & control & control & control \\
\hline Year & control & control & control \\
\hline $\mathrm{R} 2$ & 0.0232 & 0.0225 & 0.0766 \\
\hline $\mathrm{F}$ & 6.80 *** & $3.14 * * *$ & $12.38 * * *$ \\
\hline $\mathrm{N}$ & 6045 & 2891 & 3154 \\
\hline
\end{tabular}

Table 6 reports the results of multiple regression analysis of real earnings management. From the full sample regression results of real earnings management of listed companies can be seen: the nature of equity (Private) and real earnings in the 0.01 level of significant positive correlation, that is closer to the true nature of private equity, earnings management motivation is more intense, once again proved the hypothesis 1 is established; real earnings management (RM) may be the company at the same time by three methods (R_CFO, R_PROD and R_DISEXP) the nature of equity (Private) in the real earnings management control mode of R_CFO, R_PROD and R_DISEXP were significantly positive, further proof relative to the state owned holding company, real earnings management private holding company of higher degree. Real earnings management (RM) mode, although the coefficient before TOP12 is still significant, but the coefficient of TOP1 is not obvious, however, by comparison, the TOP1 coefficient was negative in R_CFO, R_PROD, R_DISEXP, TOP1 and R_DISEXP before the coefficient was significant at the 0.05 level, therefore, we there is good reason to believe that even if the effects of real earnings, concentration of shareholding and earnings management also showed a complex relationship model.

Table 6. Nature of Equity and Real Earnings Management

\begin{tabular}{|c|c|c|c|c|c|c|c|c|}
\hline & \multicolumn{2}{|c|}{$\mathrm{R}$ CFO } & \multicolumn{2}{|c|}{ R_PROD } & \multicolumn{2}{|c|}{ R_DISEXP } & \multicolumn{2}{|c|}{$\mathrm{RM}$} \\
\hline Private & $0.0185 * * *$ & {$[0.0000]$} & $0.0940 * * *$ & {$[0.0000]$} & $0.0149 * * *$ & {$[0.0000]$} & $0.1099 * * *$ & {$[0.0000]$} \\
\hline Top1 & -0.0007 & [0.1130] & -0.0026 & [0.3130] & $-0.0008^{* *}$ & {$[0.0200]$} & -0.0022 & [0.4170] \\
\hline Top12 & $0.0000^{* * * *}$ & {$[0.0010]$} & $0.0001 * *$ & {$[0.0350]$} & $0.0000^{* * * *}$ & {$[0.0010]$} & $0.0001^{* *}$ & [0.0410] \\
\hline $\mathrm{BM}$ & $-0.020 * * *$ & {$[0.0030]$} & $-0.0752^{*}$ & {$[0.0750]$} & $-0.047^{* * * *}$ & {$[0.0000]$} & $-0.142 * * *$ & {$[0.0010]$} \\
\hline SIZE & $0.0033 * * *$ & {$[0.0090]$} & $0.0225 * * *$ & {$[0.0030]$} & $0.0091 * * *$ & {$[0.0000]$} & $0.0363 * * *$ & {$[0.0000]$} \\
\hline ST & $0.0207^{* *} *$ & {$[0.0280]$} & -0.0002 & {$[0.9970]$} & 0.0021 & {$[0.7820]$} & -0.0176 & {$[0.7670]$} \\
\hline Cons & 0.0019 & [0.9470] & $-0.3608^{* *}$ & {$[0.0390]$} & $-0.112 * * *$ & {$[0.0000]$} & $-0.535 * * *$ & {$[0.0030]$} \\
\hline Industry & \multicolumn{2}{|c|}{ control } & \multicolumn{2}{|c|}{ Control } & \multicolumn{2}{|c|}{ control } & \multicolumn{2}{|c|}{ control } \\
\hline Year & \multicolumn{2}{|c|}{ control } & \multicolumn{2}{|c|}{ Control } & \multicolumn{2}{|c|}{ control } & \multicolumn{2}{|c|}{ control } \\
\hline $\mathrm{R} 2$ & \multicolumn{2}{|c|}{0.0376} & \multirow{2}{*}{\multicolumn{2}{|c|}{$\frac{0.0198}{5.80^{* * * *}}$}} & \multicolumn{2}{|c|}{0.0314} & \multicolumn{2}{|c|}{0.0249} \\
\hline F & \multicolumn{2}{|c|}{$11.19 * * *$} & & & \multicolumn{2}{|c|}{$9.29 * * *$} & \multicolumn{2}{|c|}{$7.33^{* * * *}$} \\
\hline $\mathrm{N}$ & \multicolumn{2}{|c|}{6045} & \multicolumn{2}{|c|}{$\frac{5.80 * * *}{6045}$} & \multicolumn{2}{|c|}{6045} & \multicolumn{2}{|c|}{6045} \\
\hline
\end{tabular}

The complicated relationship between ownership concentration and earnings management has aroused much interest in our research. If it contains a large number of $U$ type relationship, then the impact of ownership concentration on earnings management inflection point where? The observed range of sample points falls on the side of the 
falling $U$ type curve or more on the side of the rise. By statistics of the results of the regression, we get a summary of the results, see Table 7 .

Table 7. The Relationship between Ownership Concentration and U Type of Earnings Management

\begin{tabular}{|c|c|c|c|c|}
\hline & & Abs-DA & DA+ & R_DISEXP \\
\hline 0 & Sample points & 6045 & 2891 & 6045 \\
\hline 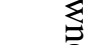 & Median & 34.2577 & 35.8518 & 34.2577 \\
\hline$\frac{0}{0}$ & Inflection point & 33.3069 & 33.9561 & 27.9155 \\
\hline$\Rightarrow$ 买. & Aggregation region & Rising zone & Rising zone & Rising zone \\
\hline 串串 & $\begin{array}{l}\text { The inflection point with the } \\
\text { median deviation rate }(\%)\end{array}$ & -2.8 & -5.2 & -18.5 \\
\hline 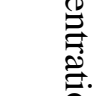 & $\begin{array}{l}\text { Sample proportion in the rise } \\
\text { area }(\%)\end{array}$ & 52.7 & 53.3 & 64.9 \\
\hline$\stackrel{\rho}{g}$ & Shareholding ratio $(\%)$ & 47.3 & 46.7 & 33.1 \\
\hline
\end{tabular}

Table 7 shows that ownership concentration and Abs-DA, DA+ and R_DISEXP type U inflection point values were $33.3069,33.9561$ and 27.9155 , and the median through the observation domain of the sample comparison can be found, and the corresponding inflection point median deviation rate (median inflection point / median) are $-2.8 \%,-5.2 \%$ and $-18.5 \%$, and the number of samples, observed in the range of rising area accounted for $52.7 \%, 53.3 \%$ and $64.9 \%$, the proportion of the first shareholder is respectively $47.3 \%$, $46.7 \%$ and $33.1 \%$, these data not only reflects the widespread $U$ relation between ownership concentration degree and the relationship between earnings management, and pointed out the position of inflection point of $U$ curve the more important is that it tells us: (1) to maintain a moderate concentration of ownership is conducive to control the manipulation of earnings management; (2) with respect to concerned should count the earnings management and real earnings management The theory has a lower concentration of ownership of the critical value, which is once again proved the hypothesis 3 , at the same time, but also enrich people's understanding.

\section{Conclusions and Policy Recommendations}

The ownership structure of our country has been quietly undergoing profound changes, try starting from the private holding company perspective, using earnings management and earnings management direction of the integration path of creative study earnings management, is conducive to the micro operation of the company, also on national macro decision is very meaningful. In this paper, A listed companies in China from 2010 to 2014 as the sample data, combined with the background of economic transformation in China, a new perspective in the private holding, using the new method and the real earnings management and negative earnings management, the ownership structure (equity nature and ownership concentration and earnings management (earnings) management, earnings management direction) of the relationship between the new comb. The study found that: (1) the earnings quality of the private holding companies is much greater than that of the state-owned holding companies. (2) the negative earnings management level of the private holding companies is significantly lower than that of the state holding companies. (3) the ownership concentration U relationship exists between the degree of earnings management, the moderate concentration of ownership is conducive to control the level of earnings management, should be concerned with respect to earnings management, real earnings management has lower ownership concentration critical value. Faced with profound changes in the ownership structure of our country, the policy suggestions are: (1) the nature of equity, continue to deepen the reform is the only way out, because of the long-term existence of soft budget constraints facing state-owned holding enterprises, to 
carry out fair competition in the rules on the basis of the private holding company, which will be the fetters of economic growth in China the pace of mixed ownership development conforms to China's national interests; (2) the ownership concentration, only based on their own practice, learn from the successful experience of others, in order to form a proxy mechanism of China's unique and long-lasting, and equity concentration moderately control the inevitable is to deepen the reform of the ownership structure of our country and success not another key.

\section{Acknowledgments}

The work of this paper is supported by Hunan Provincial Department of Education funding research projects(Project NO: 15C1250).

\section{References}

[1] L.Qingyuan, W.Hongjian, "Financial crisis, government subsidies and earnings exercise -- Empirical Evidence from Chinese listed companies", Managing the world, Vol.7,( (2014), pp.157-167.

[2] M.Xiaoqing, C.Xiao, "The protective effect of the substitution of state owned stock investors: Theory and empirical evidence", Economist, Vol.1,(2009) ,pp.48-60.

[3] L.Liguo, D.Ying, "An empirical study on the relationship between corporate governance and accounting information quality", Accounting research, Vol.2,(2003),pp. 28-36.

[4] B.Ray, and G.Foster, "Corporate financial reporting: A methodological review of empirical research", Journal of accounting Research ,Vol.11, (1982),pp.161-234.

[5] Cohen, D, A, Zarowin P. Accrual-based and real earnings management activities around seasoned equity offerings. Journal of Accounting and Economics, Vol.1,(2010),pp.2-19.

[6] Dechow, Patricia M., Richard G. Sloan, and Amy P. Sweeney. "Detecting earnings management." Accounting Review, (1995),pp.193-225.

[7] Dechow, P., Sloan, R., Sweeney, A.Causes and consequences of earnings manipulation: An analysis of firms subject to enforcement actions by the sec. Contemporary accounting research, 1996, 13,pp. 1-36.

[8] D. Mark, and W. Park. "Smoothing income in anticipation of future earnings." Journal of accounting and economics, Vol.23, (1997) ,pp.115-139.

[9] Dechow, Patricia M., Sagar P. Kothari, and Ross L Watts. "The relation between earnings and cash flows." Journal of Accounting and Economics 25.2 (1998) ,pp.133-168.

[10] Graham J R, Harvey C R, Rajgopal S. The economic implications of corporate financial reporting. Journal of accounting and economics, Vol.4,(2005),pp.3-73.

[11] Gunny K A. What are the consequences of real earnings management? 2005,pp.11-20.

[12] Fama, Eugene F., and Kenneth R. French. "Industry costs of equity." Journal of financial economics 43.2 (1997),pp. 153-193.

[13] Kothari, Sagar P., Andrew J. Leone, and Charles E. Wasley. "Performance matched discretionary accrual measures." Journal of accounting and economics ,Vol.139, (2005) ,pp. 163-197.

[14] Kato, Takao, and Cheryl Long. "Executive turnover and firm performance in China." The American economic review, Vol.12, (2006), pp.363-367.

[15] Murphy, Kevin J., and Jerold L. Zimmerman. "Financial performance surrounding CEO turnover." Journal of Accounting and Economics ,Vol.16, (1993),pp. 273-315.

[16] Monks, Robert AG, and Nell Minow. "Corporate Govemance." (1995) ,pp.12-20.

[17] Shleifer, Andrei, and Robert W. Vishny. "Management entrenchment: The case of manager-specific investments." Journal of financial economics, Vol.2, (1989) ,pp. 123-139.

[18] Teoh, Siew Hong, Ivo Welch, and Tak Jun Wong. "Earnings management and the long-run market performance of initial public offerings." The Journal of Finance , Vol.53, (1998) ,pp. 1935-1974.

[19] Roychowdhury, Sugata. "Earnings management through real activities manipulation." Journal of accounting and economics,Vol.4, (2006) ,pp.335-370.

[20] Zang A Y. Evidence on the tradeoff between real manipulation and accrual manipulation. ProQuest, 2006, pp.20-23. 


\section{Authors}

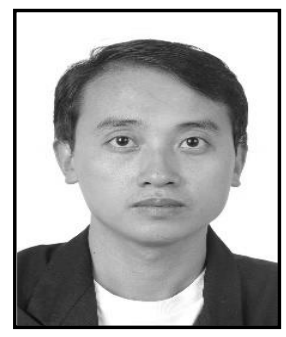

Liu Hong-Tao, 1976.12, Shaoyang University, China, Current position, grades: Lecturer, Department of Economics and Management, Shaoyang University, Hunan, China. Scientific interest: He research interest fields include ecological economy and ecological management. Publications: More than 10 papers published. Experience: He has teaching experience of 6 years, has completed three scientific research projects. 
International Journal of Database Theory and Application Vol.10, No.1 (2017) 